\title{
Reducing the Risks of New Coronavirus in Vulnerable Areas in Brazil
}

\begin{abstract}
The new coronavirus (SARS-CoV-2) has not yet reached its peak ${ }^{1}$ of infections in Brazil ${ }^{2}$. Yet it has already caused significant disruptions to the life of people across the country. The higher rate of confirmed cases and deaths have so far been concentrated in urban areas. However, it is only a matter of weeks for this lethal virus to reach remote and poor areas in the rural part of the country. When this happens, it will wreak havoc. This paper thus proposes a policy deriving from a risk assessment for local leaders from these areas. The expectation is that this strategy designed for impoverished and deprived areas can contribute to reduce the risk of the horrendous effects that this pathogen can have in these vulnerable communities and their fragile economies.
\end{abstract}

Keywords: new coronavirus, public policy, Brazil, vulnerability, poverty

\section{Background}

The current public health crisis caused by the new coronavirus poses catastrophic risks ${ }^{3}$ to remote ('rural') and/or poor ${ }^{4}$ municipalities and communities ('areas') in Brazil ${ }^{5}$. Such areas have been largely ignored ${ }^{6}$ by central authorities at this stage of this unprecedented global crisis. The

\footnotetext{
${ }^{1}$ Cambricoli, F., Felix, P., Girardi, G., 2020. Coronavírus já pressiona SUS e hospitais privados em São Paulo. UOL, viewed 3 April 2020

$<$ https://noticias.uol.com.br/ultimas-noticias/agencia-estado/2020/04/02/covid-ja-pressiona-sus-e-hospitai s-privados-em-sp.htm>

${ }^{2}$ Fioravanti, C., 2020. Pesquisadora diz que o pico da covid-19 no Brasil ocorrerá entre abril e maio. UOL, viewed 2 April 2020

<https://www.uol.com.br/vivabem/noticias/redacao/2020/03/14/pesquisadora-diz-que-pico-da-covid-19-no -brasil-ocorrera-entre-abril-e-maio.htm>

${ }^{3}$ Ifad, 2020. COVID-19. International Fund for Agricultural Development (Ifad), viewed 2 April 2020 $<$ https://www.ifad.org/en/covid19>

${ }^{4}$ Zibell, M., 2020. Coronavirus en Ecuador: el drama de Guayaquil, que tiene más muertos por covid-19 que países enteros y lucha a contrarreloj para darles un entierro digno. BBC, viewed 2 April 2020 <https://www.bbc.com/mundo/noticias-america-latina-52116100>

${ }^{5}$ Wenzel, F. 2020. Coronavírus: Casos Suspeitos em Mineradora Acendem Alerta sobre Comunidades da Amazônia. The Intercept Brasil, viewed 2 April 2020

<https://theintercept.com/2020/03/18/mineradora-casos-coronavirus-comunidades-amazonia/>

${ }^{6}$ Instituto Socioambiental, 2020. Quilombolas divulgam nota contra plano do governo de remover comunidades em meio à pandemia. Instituto Socioambiental, viewed 2 April 2020

<https://www.socioambiental.org/pt-br/noticias-socioambientais/quilombolas-divulgam-nota-contra-planodo-governo-de-remover-comunidades-em-meio-a-pandemia>
} 
federal and state governments have been more concerned about reducing the rates of community transmission in large urban areas ${ }^{7}$ since they have reported the first cases for COVID-19. The good news is that many remote and/or poor ${ }^{8}$ areas have not yet reported official cases of the new coronavirus. The bad news is that intra and/or interstate movement of people is still happening ${ }^{9}$. Thus it is only a matter of time for the first official cases to occur and exponentially increase. And once they start, it might be too late for these impoverished and deprived areas to avoid significant human and economic losses. These areas will also be unable $^{10}$ to reverse these losses in the short and medium terms. This article, therefore, aims to provide a feasible action plan that elected officials and community leaders from remote and poor areas can immediately take to contain the spread of new coronavirus while keeping to a minimum social and economic disruptions within their areas during this pandemic. The policy proposed in this article is called 'Island Resizing'.

\section{Proposed Policy}

'Island Resizing' argues for a shift in mindset ${ }^{11}$ among decision makers. Local leaders are urged to physically disconnect ${ }^{12}$ from medium and large urban areas. They need to quickly plan their communities to become 'islands' in their region for as long ${ }^{13}$ as this global crisis lasts. And after

\footnotetext{
${ }^{7}$ Governo do Brasil, 2020. Coronavírus: saiba como o Governo Federal está agindo. Governo do Brasil, viewed 2 April 2020

<https://www.gov.br/pt-br/noticias/saude-e-vigilancia-sanitaria/2020/01/coronavirus-saiba-como-o-govern o-federal-esta-agindo>
}

${ }^{8}$ Globo, 2020. Casos de coronavírus no Brasil e no mundo. Globo.com, viewed 2 April 2020

$<$ https://especiais.g1.globo.com/bemestar/coronavirus/mapa-coronavirus/? ga=2.179676388.194436739 3.1585620742-1165563831.1583596947\#/>

${ }^{9}$ Canal Rural, 2020. Quem vive na zona rural deve evitar grandes centros urbanos, diz secretário do Ministério da Saúde. Canal Rural, viewed 2 April 2020

$<$ https://www.canalrural.com.br/agronegocio/quem-vive-na-zona-rural-deve-evitar-grandes-centros-urban os-diz-secretario-do-ministerio-da-saude/>

${ }^{10}$ Agência Brasil, 2020. Banco Mundial e FMI pedem alívio de dívida para países mais pobres, Agência Brasil, viewed 2 April 2020

$<$ https://agenciabrasil.ebc.com.br/internacional/noticia/2020-03/banco-mundial-e-fmi-pedem-alivio-de-divi da-para-paises-mais-pobres>

${ }^{11}$ Aylward, B. 2020. Countries must shift mindset to coronavirus preparedness: WHO expert, Global News, viewed 2 April 2020

<https://globalnews.ca/video/6595889/countries-must-shift-mindset-to-coronavirus-preparedness-who-ex pert>

${ }^{12}$ Aylward, B. 2020. WHO expert urges the world to copy China's response to COVID-19, CGTN, viewed 2 April $2020<$ <ttps://www.youtube.com/watch?v=aq1XKw5IKxM>

${ }^{13}$ Bootsma, M.C. and Ferguson, N.M., 2007. The effect of public health measures on the 1918 influenza pandemic in US cities. Proceedings of the National Academy of Sciences, 104(18), pp.7588-7593. 
isolating themselves, they need to be ready to quickly adapt ${ }^{14}$, or 'resize' ${ }^{\prime 15}$ their areas, to the risk of community transmission by creating islands within islands through delineating inner 'boundaries'16 to isolate suspected cases. 'Island Resizing', therefore, is a policy strategy guiding local decision makers on how they can protect their vulnerable ${ }^{17}$ residents with minimum resources. It is a flexible method that permits impoverished and deprived areas to quickly adapt to moving targets. It is an ongoing methodology that proposes the establishment of temporary 'boundaries', or 'cordon sanitaire'18, that start from outer city limits and could trickle down to smaller units such as nursing homes. The main assumption of this strategy is that local leaders are committed to protect the most vulnerable residents and have the means to quickly establish and enforce different sizes of these 'boundaries' for as long as it is required.

\section{Method}

The factor determining the extension of and where these 'boundaries' are to be delineated depends on the risk level of each municipality or community to the new coronavirus.

If local leaders deem that the area or many residents fall into the category of high-risk to this disease, a 'boundary' around the most vulnerable should be immediately established.

However, if there is no sign that this disease has reached a high-risk municipality or community yet, local decision makers need to quickly consider establishing a 'boundary' around the city or community limits. Outer 'boundaries' must allow only essential ${ }^{19}$ services and goods

\footnotetext{
${ }^{14}$ World Health Organization, 2020. Report of the WHO-China Joint Mission on Coronavirus Disease 2019 (COVID-19). 2020, p.19, viewed 2 April 2020 $<$ https://www.who.int/docs/default-source/coronaviruse/who-china-joint-mission-on-covid-19-final-report.p $\underline{\mathrm{df}>}$

${ }^{15}$ Cohen, J., Kupferschmidt, K. 2020. The coronavirus seems unstoppable. What should the world do now?, Science, viewed 2 April 2020

<https://www.sciencemag.org/news/2020/02/coronavirus-seems-unstoppable-what-should-world-do-now>

${ }^{16}$ Hatchett, R.J., Mecher, C.E. and Lipsitch, M., 2007. Public health interventions and epidemic intensity during the 1918 influenza pandemic. Proceedings of the National Academy of Sciences, 104(18), pp.7582-7587.

${ }^{17}$ Reis, C.; Lawry, L. L., 2020. These groups are among the most vulnerable during the COVID-19 pandemic, The Conversation, viewed 2 April 2020 $<$ https://theconversation.com/these-groups-are-among-the-most-vulnerable-during-the-covid-19-pandemi c-133774>

${ }^{18}$ Benjamin, G.C., 2006. Pandemic influenza: Preparing for the worst. Administrative Law Review, pp.663-666.

${ }^{19}$ COVID-19 Alert Level 4 Transport, 2020. Ministry of Transport, New Zealand, viewed 2 April 2020 $<$ https://www.transport.govt.nz/about/covid-19-alert-level-4-transport-essential-services/>
} 
to be brought in. This is to keep the rapid ${ }^{20}$ spread of this virus at bay while minimizing ${ }^{21}$ the risk of disruptions to existing social and economic activities.

These 'boundaries' need to be in place for the entire duration of this pandemic. However, 'boundaries' around smaller units such as nursing homes can be gradually dispersed ${ }^{22}$ after residents within that boundary have not presented symptoms to COVID-19 after a three-week ${ }^{23}$ quarantine. These vulnerable residents are then encouraged ${ }^{24}$ to return home. However, they are strongly advised to keep strict hygiene standards and maintain recommended social distance ${ }^{25}$ either at home or in public. Such precautionary measures aim to reduce the risk of vulnerable residents to be in contact with people unknown to be infected and showing no symptoms but still transmissible ${ }^{26}$ to those in close contact with them.

\section{Risk Assessment and Action Plan}

Figure: Risk Assessment

${ }^{20} \mathrm{Qiu}, \mathrm{J} ., 2020$. Covert coronavirus infections could be seeding new outbreaks, Nature, viewed 2 April $2020<$ https://www.nature.com/articles/d41586-020-00822-x>

${ }^{21}$ Ghebreyesus, T. A., 2020. WHO Director-General's opening remarks at the media briefing on COVID-19 - 11 March 2020, World Health Organization, viewed 2 April 2020

$<$ https://www.who.int/dg/speeches/detail/who-director-general-s-opening-remarks-at-the-media-briefing-o n-covid-19---11-march-2020>

${ }^{22}$ Fottrell, Q., 2020. Anthony Fauci says coronavirus 'might keep coming back' year after year - 'the ultimate game changer in this will be a vaccine', Market Watch, viewed 3 April 2020

$<$ https://www. marketwatch.com/story/anthony-fauci-says-coronavirus-might-keep-coming-back-year-afteryear-the-ultimate-game-changer-in-this-will-be-a-vaccine-2020-04-02>

${ }^{23}$ Pomeroy, R., 2020. Can I go for a run? When will this end? How should testing work? A WHO expert on coronavirus explains, World Economic Forum, viewed 2 April 2020

<https://www.weforum.org/agenda/2020/03/how-to-stop-covid-19-find-test-isolate-treat/>

${ }^{24}$ Gupta, S., 2020. Social distancing comes with psychological fallout. Science News, viewed 2 April 2020 <https://www.sciencenews.org/article/coronavirus-covid-19-social-distancing-psychological-fallout>

${ }^{25}$ Dalton, C.B., Corbett, S.J. and Katelaris, A.L., 2020. Pre-emptive low cost social distancing and enhanced hygiene implemented before local COVID-19 transmission could decrease the number and severity of cases. SSRN, 3549276.

${ }^{26}$ Qiu, J., 2020. Covert coronavirus infections could be seeding new outbreaks, Nature, viewed 2 April $2020<$ https://www.nature.com/articles/d41586-020-00822-x> 


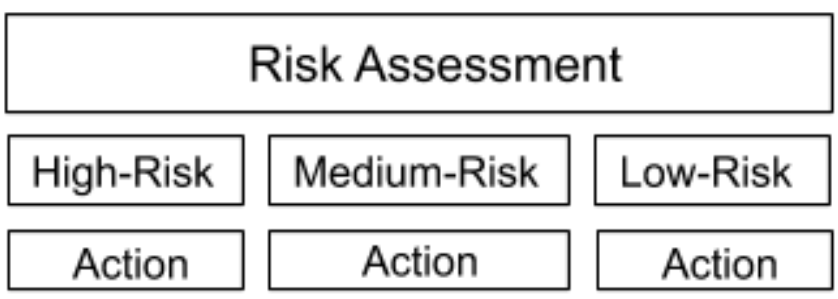

(source: author)

\section{General Criteria for Risk Assessment:}

. community transmission rate in the region

. number and condition ${ }^{27}$ of vulnerable individuals in a municipality or community

. local capacity to establish and enforce temporary boundaries

High-risk areas are those featuring:

. evidence of community transmission in municipalities nearby

. a great number of individuals travelling from community transmission areas

. featuring large number of vulnerable residents

Actions:

. assume that every resident is already infected ${ }^{28}$

. enforce a three-week home quarantine to all residents

. provide access to essential ${ }^{29}$ goods and services

. establish a boundary around the city and allow only the entry of essential goods and services

. establish a boundary around small units such as nursing homes and local medical centers ${ }^{30}$

. train $^{31}$ few people from low-risk ${ }^{32}$ groups $^{33}$ to care for isolated vulnerable groups

${ }^{27}$ Sawaya, A.L., Solymos, G.M.B., Florêncio, T.M.D.M.T. and Martins, P.A., 2003. Os dois Brasis: quem são, onde estão e como vivem os pobres brasileiros. Estudos avançados, 17(48), pp.21-44.

${ }^{28}$ Gupta, S., 2020. Dr. Gupta's advice: Act as if you might be carrying the virus. CNN, viewed 2 April 2020 <https://edition.cnn.com/videos/health/2020/03/18/gupta-act-like-you-have-the-coronavirus-sot-vpx.cnn>

${ }^{29}$ HRW, 2020. India: COVID-19 Lockdown Puts Poor at Risk. Human Rights Watch, viewed 2 April 2020 <https://www.hrw.org/news/2020/03/27/india-covid-19-lockdown-puts-poor-risk>

${ }^{30}$ Sukevicius, R., 2020. Coronavírus faz hospital confinar médicos e pacientes por quase dois meses em SP. UOL, viewed 2 April 2020

<https://www1.folha.uol.com.br/equilibrioesaude/2020/03/coronavirus-faz-hospital-confinar-medicos-e-pa cientes-por-quase-dois-meses-em-sp.shtml>

${ }^{31}$ Diário Oficial da União, 2020. PORTARIA Nº 639, DE 31 DE MARÇO DE 2020, Ministério da Saúde/Gabinete do Ministro, viewed 3 April 2020

<http://www.in.gov.br/en/web/dou/-/portaria-n-639-de-31-de-marco-de-2020-250847738>

${ }^{32}$ ASMS, 2020. National guidance for DHBs to reduce risk of COVID-19 infection of vulnerable or at-risk staff, Association of Salaried Medical Specialists, viewed 2 April 2020 
Medium-risk areas are those featuring:

. evidence of community transmission in the region

. recent influx of travellers from community transmission areas

. few number of vulnerable residents

Actions:

. establish a boundary around the city and allow only the entry of essential goods and services . establish boundaries around small units such as nursing homes and local medical centers

Low-risk areas are those featuring:

. no evidence of community transmission in the region

. no travellers from community transmission areas over the last three weeks

Action:

. establish a boundary around the city and allow only the entry of essential goods and services

\section{Limitations}

There are important limitations to the proposed policy. The first one is how local leaders can accurately determine the risk level of their area due to lack of accurate ${ }^{34}$ official data. The assessment of this risk level is essential as it determines when and where 'boundaries' should be established and gradually dispersed. The second limitation is the enforcement ${ }^{35}$ of these boundaries. Local authorities must warn about upcoming ${ }^{36}$ lockdowns. They also need to be aware that the longer these 'boundaries' are in place, the more resources they will need to ensure outsiders and insiders do not not break through the blockade. The third limitation has to

<https://www.asms.org.nz/wp-content/uploads/2020/03/1.-COVID-19-DHB-Vulnerable-Workforce-Risk-As sessment-Framework-for-Staff-I-23-Mar-2020-v1.0-1.pdf>

${ }^{33}$ Verity, R., Okell, L.C., Dorigatti, I., Winskill, P., Whittaker, C., Imai, N., Cuomo-Dannenburg, G., Thompson, H., Walker, P.G., Fu, H. and Dighe, A., 2020. Estimates of the severity of coronavirus disease 2019: a model-based analysis. The Lancet Infectious Diseases.

${ }^{34}$ Cornwall, W., 2020. Can you put a price on COVID-19 options? Experts weigh lives versus economics, Science, viewed 2 April 2020

$<$ https://www.sciencemag.org/news/2020/03/modelers-weigh-value-lives-and-lockdown-costs-put-price-co vid-19>

${ }^{35}$ Kidangoor, A., 2020. Modi's Hasty Coronavirus Lockdown of India Leaves Many Fearful for What Comes Next, Time, viewed 2 April 2020 <https://time.com/5812394/india-coronavirus-lockdown-modi/>

${ }^{36}$ NewstalkZB, 2020. Civil Defence coronavirus lockdown warning sent to all Kiwi phones, NewstalkZB, viewed 2 April 2020

<https://www.newstalkzb.co.nz/news/national/coronavirus-civil-defence-alert-where-you-stay-tonight-is-w here-you-must-stay-during-lockdown/> 
do with the psychological toll ${ }^{37}$ that such boundaries impose on isolated communities inside and outside these areas. The longer they are imposed, the greater the risks are for social unrest.

\section{Conclusion}

Despite these limitations, this paper argues that such actions should be considered by local leaders from remote and poor areas to contain ${ }^{38}$ the spread of new coronavirus within their communities. This is because the risk posed by the new coronavirus to vulnerable groups living in impoverished and deprived areas is significantly higher than the one observed in urban places with resources to enact interventions ${ }^{39}$ to contain community transmission and to mitigate the rate of hospitalizations. Testing ${ }^{40}$ and hospitalization are not a reality for remote and/or poor areas, so local leaders requested ${ }^{41}$ some guidance ${ }^{42}$ on what they can actively start doing to protect the most vulnerable individuals and their local economy in this moment of great uncertainty. Finally, 'Island Resizing', as a policy strategy, is not an assurance that remote and poor areas will come away from this global crisis unscathed. The main motivation in proposing such a policy is to help local leaders reduce ${ }^{43}$ the risks of community transmission within impoverished and deprived areas while protecting their most vulnerable residents and limiting losses to the local economy.

${ }^{37}$ Brooks, S.K., Webster, R.K., Smith, L.E., Woodland, L., Wessely, S., Greenberg, N. and Rubin, G.J., 2020. The psychological impact of quarantine and how to reduce it: rapid review of the evidence. The Lancet.

${ }^{38}$ Anderson, R.M., Heesterbeek, H., Klinkenberg, D. and Hollingsworth, T.D., 2020. How will country-based mitigation measures influence the course of the COVID-19 epidemic?. The Lancet, 395(10228), pp.931-934.

${ }^{39}$ Shieber, J., 2020. US response to the COVID-19 coronavirus moves from 'containment' to 'mitigation'. Tech Crunch, viewed 2 April 2020

$<$ https://techcrunch.com/2020/03/08/u-s-response-to-the-covid-19-coronavirus-moves-from-containmento-mitigation/>

${ }^{40}$ Martins, R. 2020. ENTREVISTA: 'O NÚMERO DE INFECTADOS POR CORONAVÍRUS PODE SER MUITO MAIOR QUE 11 CASOS PARA CADA CONFIRMADO' DIZ SANITARISTA, The Intercept Brasil, viewed 2 April 2020

<https://theintercept.com/2020/03/31/entrevista-sanitarista-faltam-testes-coronavirus/>

${ }^{41}$ Guimarães, L., 2020. Favelas serão as grandes vítimas do coronavírus no Brasil, diz líder de Paraisópolis. BBC, viewed 2 April 2020 <https://www.bbc.com/portuguese/brasil-51954958>

${ }^{42}$ Cypreste, J., Konchinski, V., 2020. Coronavírus chega ao interior e pequenas cidades viram foco de transmissão, UOL, viewed 3 April 2020

$<$ https://noticias.uol.com.br/saude/ultimas-noticias/redacao/2020/04/02/coronavirus-chega-ao-interior-e-p equenas-cidades-viram-foco-de-transmissao.htm>

${ }^{43}$ Ferguson, N.M., Laydon, D., Nedjati-Gilani, G., Imai, N., Ainslie, K., Baguelin, M., Bhatia, S., Boonyasiri, A., Cucunubá, Z., Cuomo-Dannenburg, G. and Dighe, A., Impact of non-pharmaceutical interventions (NPIs) to reduce COVID19 mortality and healthcare demand. 16 March 2020. 
Acknowledgement

No conflict of interest to report. No funding to declare. 